\title{
The pine wood nematode, Bursaphelenchus xylophilus, in Portugal: possible introductions and spread routes of a serious biological invasion revealed by molecular methods
}

\author{
Vera VAladas ${ }^{1}$, Marta LARANJO ${ }^{2,3}$, Pedro Barbosa ${ }^{1}$, Margarida EsPadA ${ }^{1}$, \\ Manuel Mota ${ }^{1, *}$ and Solange Oliveira ${ }^{2}$ \\ ${ }^{1}$ NemaLab-ICAAM \& Departamento de Biologia, Universidade de Évora, Évora, Portugal \\ ${ }^{2}$ Lab. Microbiologia do Solo-ICAAM \& Departamento de Biologia, Universidade de Évora, Évora, Portugal \\ ${ }^{3}$ IIFA (Instituto de Investigação e Formação Avançada), Universidade de Évora, Évora, Portugal
}

Received: 15 December 2011; revised: 14 February 2012

Accepted for publication: 17 February 2012; available online: 2 May 2012

\begin{abstract}
Summary - The pine wood nematode (PWN), Bursaphelenchus xylophilus, the causal agent of pine wilt disease (PWD), is a major world-wide pathogen and pest of pine, with impacts on forest health, natural ecosystem stability and international trade. In Portugal, PWN was first diagnosed in 1999, the first occurrence also for Europe. The disease was recently detected on the island of Madeira and in northern Spain. In an attempt to search for more reliable and robust molecular markers that enable the study of intraspecific variability of B. xylophilus from different geographic locations, the intergenic spacer (IGS) region of the 5S rRNA gene and inter-simple sequence repeats (ISSR) analysis were used to determine the genetic relationships among 43 B. xylophilus isolates from Portugal, China, Japan, South Korea and USA. IGS sequence analysis showed that this region can only be used to establish interspecific relationships, since no differences were detected among Portuguese isolates from different geographic locations. Fingerprints obtained with ISSR show high genetic variability among Portuguese isolates, except for the ones obtained prior to 2008. The ISSR dendrogram suggests the spread of the disease inside continental Portugal and to Madeira. Until 2008, B. xylophilus populations found in continental Portugal showed low genetic diversity, pointing to a single introduction, probably from Asia, whereas recent populations from continental Portugal (2009-2010) and Madeira show high genetic diversity, suggesting multiple introductions from different origins.
\end{abstract}

Keywords - genetic diversity, IGS ISSR, intraspecific variability, ITS, molecular marker, pine wilt disease.

The pine wood nematode (PWN), Bursaphelenchus xylophilus (Steiner \& Buhrer, 1934; Fuchs, 1937), is indigenous to North America and is widespread in natural coniferous forests in Canada and USA (Sutherland \& Peterson, 1999). At present, B. xylophilus is considered one of the most important pests and pathogens in the world (Webster \& Mota, 2008). The general fear of establishment of PWN, the causal agent of pine wilt disease (PWD), into countries where conifer forests assume great importance, stems from the devastating damage caused by this nematode to pine forests (Mamiya, 2004; Shin \& Han, 2006). The introduction of PWN into non-native areas (outside of North America) is primarily associated with trade and the global flow of forest products (Bergdahl \& Halik, 1999; Webster, 2004). Non-manufactured wood, especially in raw log form, has been identified as one of the most high-risk pathways of biological invasions, carrying forest insects and pathogens into new environments (Evans et al., 1996; Tkacz, 2002). Many Bursaphelenchus species, including the PWN, have been routinely intercepted in packaging and wood products in several countries, e.g., Austria (Tomiczek et al., 2003), China (Gu et al., 2006), Finland (Tomminen et al., 1991) and Germany (Braasch et al., 2001). Furthermore, recent detection of PWN in packaging wood imported from countries considered free of this pest, due to the repeated use and circulation of this type of wood material, e.g., Brazil, Belgium, Italy and Spain (Gu et al., 2006), undoubtedly underlines the importance of trade globalisation for the potential entry/establishment of this pathogen into endemic forests worldwide.

\footnotetext{
*Corresponding author, e-mail: mmota@uevora.pt
} 
The introduction and spread of this nematode has resulted in huge annual losses due to the rise in mortality and growth loss of pine forest, and to the increased costs of management procedures and disease control (Mamiya, 2004; Shimazu, 2006). In addition, the introduction of PWN has resulted in vast and irreversible changes to native forest ecosystems, including tree species conversions, wildlife habitat destruction, soil and water conservation and loss of biodiversity (Kiyohara \& Bolla, 1990; Suzuki, 2002). The PWN has already been established for more then 100 years in Japan (Yano, 1913) and, in the past two decades, new reports of PWD came mainly from East Asia (Cheng et al., 1983; Yi et al., 1989).

In 1999, PWN was reported for the first time in Portugal and in Europe (Mota et al., 1999), collected from dead maritime pine (Pinus pinaster) trees located in the Setúbal Peninsula, $30 \mathrm{~km}$ south east of Lisbon. During approximately 10 years, PWN was confined to the Setúbal Peninsula, occupying 510000 ha of the continental area. Despite efforts implemented by the Portuguese authorities to control this quarantine nematode, by 2008 new areas of the disease were established in other regions of the country (Rodrigues, 2008), and, more recently, PWN was detected on Madeira, $1000 \mathrm{~km}$ south west of continental Portugal (Fonseca et al., 2010). Recently, it has also been detected in Spain (Abelleira et al., 2011; Robertson et al., 2011). Therefore, it is of major importance to determine the origin of the new isolates and their spread routes to prevent further dissemination of the disease across Europe.

Sequence analysis of specific regions of genomic DNA has proved to be an effective approach for species identification. Ribosomal internal transcribed spacer regions ITS1 and ITS2 are positioned between the small rRNA subunit (SSU), the 5.8S rRNA gene and the large rRNA subunit (LSU). ITS is an excellent marker for quickly distinguishing among known species, due to its low level of intraspecific polymorphisms and sequence variation (Blouin, 2002). On the other hand, the intergenic spacer (IGS) region of the 5S rRNA gene is known to be highly variable, even between closely related species such as $B$. xylophilus and B. mucronatus (Kang et al., 2004). It has also been useful to study species at the intraspecific level, such as, for example, the fungus Fusarium oxysporum (Kim et al., 2001). Inter-simple sequence repeats (ISSR) are commonly used to study intraspecific variation and evaluate genetic diversity. This method was described for eukaryotes in general (Zietkiewicz et al., 1994), but has been predominantly applied to plants (Reddy et al., 2002). Studies of animal ISSR polymorphisms have been useful in analysing the pathway of introduced species (Abbot, 2001; Metge et al., 2006). ISSR provides informative markers because they are highly polymorphic. ISSR markers are highly reproducible due to stringent annealing temperatures, long primers, and low primer-template mismatch (semi-arbitrary primers that anchor on SSR loci) (Jones et al., 1997).

In this study, our main goal was to understand the widespread patterns of B. xylophilus isolates from Portugal and Madeira, comparing them with foreign isolates by using two distinct approaches: sequence analysis of IGS region and ISSR analysis.

\section{Materials and methods}

\section{NEMATODE SAMPLING AND CULTURE}

In the present study, 34 B. xylophilus isolates from Portugal (continental and the island of Madeira; Fig. 1) were used (Table 1). Madeira isolates were provided by the Nematology Laboratory, IMAR-CMA (Department of Life Sciences, University of Coimbra), and continental Portugal isolates were provided by AFN (National Forest Authority) from the national surveys made each year. Each isolate was obtained from a wood sample collected from one tree. A Portuguese isolate of the closely related species B. mucronatus was used as outgroup. Nine foreign isolates from China, Japan, South Korea and USA were used as reference (Table 1). Isolates were maintained in the laboratory in barley seed cultures grown with Botrytis cinerea at $25^{\circ} \mathrm{C}$ (Y. Mamiya, pers. commun.). The nematodes were extracted from cultures using the Baermann funnel technique (Southey, 1986). After this, nematodes were collected and concentrated in $1.5 \mathrm{ml}$ microtubes in a minimum amount of distilled water.

\section{DNA EXTRACTION}

Genomic DNA was obtained from a $50 \mu \mathrm{l}$ suspension containing more than 10000 nematodes from each isolate

Fig. 1. Map of the geographical distribution of Bursaphelenchus xylophilus isolates in continental Portugal and Madeira Island, showing the sampling sites of isolates collected until 2008 and in 2009-2010. Isolates code and symbol, representing sampling year, are shown in Table 1. 


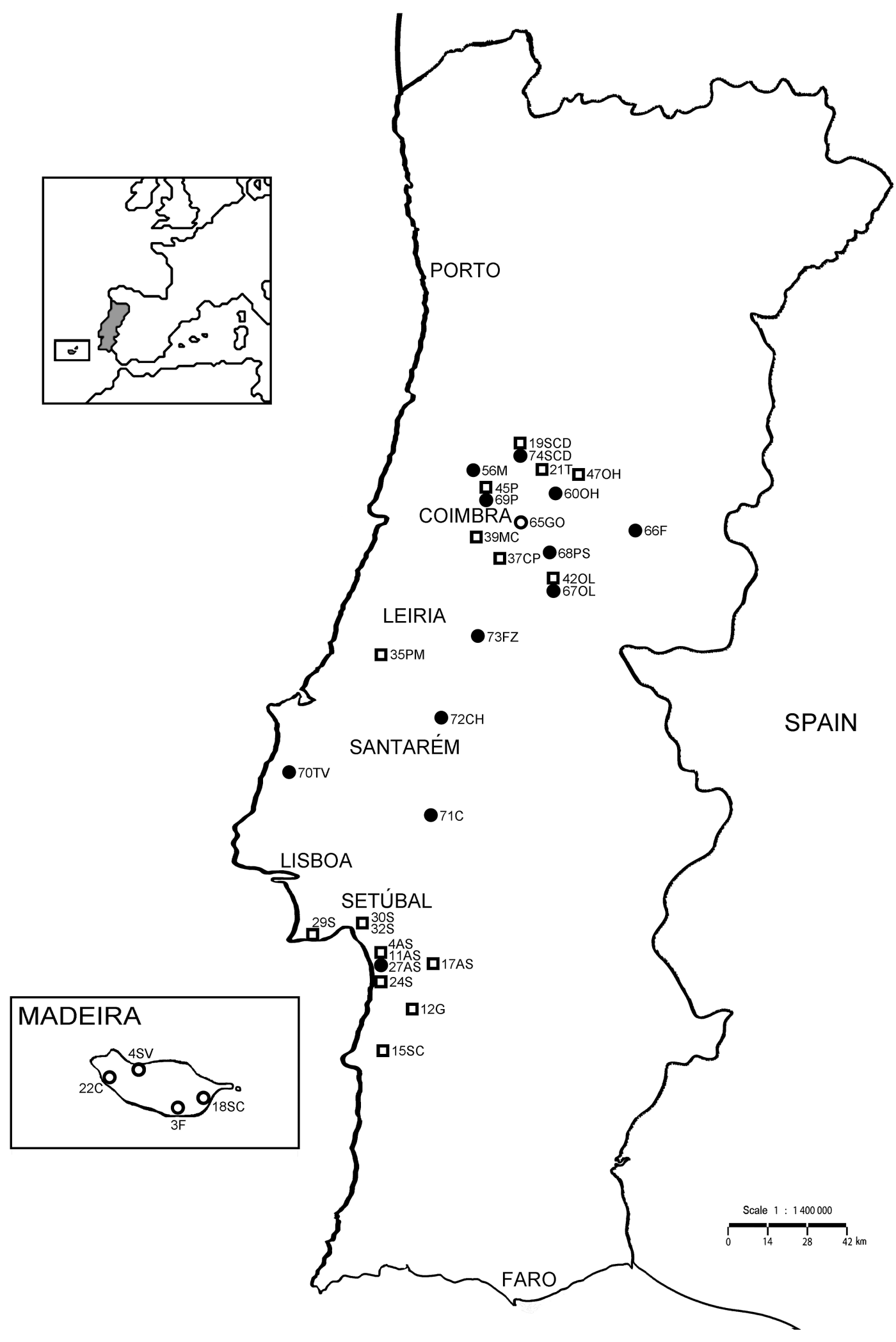


V. Valadas et al.

Table 1. List of Bursaphelenchus xylophilus isolates used in the present study; location, year of culture, map symbol (sampling year), code, accession numbers of ITS and IGS sequences.

\begin{tabular}{|c|c|c|c|c|c|c|}
\hline \multirow[t]{2}{*}{ Country } & \multirow[t]{2}{*}{ Geographic location } & \multirow[t]{2}{*}{ District } & \multirow{2}{*}{$\begin{array}{l}\text { Year of } \\
\text { culture }\end{array}$} & \multirow[t]{2}{*}{ Map symbol/Code } & \multicolumn{2}{|c|}{ Accession numbers } \\
\hline & & & & & ITS sequences & IGS sequences \\
\hline \multirow[t]{30}{*}{ Portugal } & Alcácer do Sal & Setúbal & 2005 & $\square \mathrm{BxPt} 4 \mathrm{AS}$ & JN684822 & JN684853 \\
\hline & Alcácer do Sal & Setúbal & 2005 & 口BxPt11AS & JN684827 & JN684854 \\
\hline & Grândola & Setúbal & 2006 & 口BxPt12G & JN684828 & JN684856 \\
\hline & Santiago do Cacém & Setúbal & 2007 & 口BxPt15SC & JN684829 & JN684857 \\
\hline & Alcácer do Sal & Setúbal & 2007 & 口BxPt17AS & JN684830 & JN684855 \\
\hline & Santa Comba Dão & Coimbra & 2008 & 口BxPt19SCD & JN684831 & JN684861 \\
\hline & Tábua & Coimbra & 2008 & aBxPt21T & JN684832 & JN684862 \\
\hline & Grândola & Setúbal & 1999 & 口BxPt24S & JN684823 & JN684852 \\
\hline & Alcácer do Sal & Setúbal & 2009 & BxPt27AS & JN684826 & JN684860 \\
\hline & Setúbal & Setúbal & 1999 & 口BxPt29S & JN684821 & JN684851 \\
\hline & Setúbal & Setúbal & 2008 & 口BxPt30S & JN684825 & JN684858 \\
\hline & Setúbal & Setúbal & 2008 & 口BxPt32S & JN684824 & JN684859 \\
\hline & Porto de Mós & Leiria & 2008 & 口BxPt35PM & JN684333 & JN684866 \\
\hline & Castanheira de Pêra & Leiria & 2008 & 口BxPt37CP & JN684834 & JN684867 \\
\hline & Miranda Corvo & Leiria & 2008 & 口BxPt39MC & JN684835 & JN684868 \\
\hline & Oleiros & Castelo Branco & 2008 & 口BxPt42OL & JN684836 & JN684869 \\
\hline & Penacova & Castelo Branco & 2008 & 口BxPt45P & JN684837 & JN684870 \\
\hline & Oliveira do Hospital & Castelo Branco & 2008 & 口BxPt47OH & JN684838 & JN684871 \\
\hline & Mealhada & Coimbra & 2009 & BxPt56M & JN684839 & JN684863 \\
\hline & Oliveira do Hospital & Coimbra & 2009 & BxPt60OH & JN684840 & JN684864 \\
\hline & Goís & Coimbra & 2010 & OBxPt65GO & JN684841 & JN684865 \\
\hline & Fundão & Castelo Branco & 2009 & BxPt66F & JN684842 & JN684872 \\
\hline & Oleiros & Castelo Branco & 2009 & OBxPt67OL & JN684843 & JN684873 \\
\hline & Pampilhosa da Serra & Coimbra & 2009 & BxPt68PS & JN684844 & JN684874 \\
\hline & Penacova & Coimbra & 2009 & BxPt69P & JN684845 & JN684875 \\
\hline & Torres Vedras & Lisboa & 2009 & OBxPt70TV & JN684846 & JN684876 \\
\hline & Coruche & Santarém & 2009 & BxPt71C & JN684847 & JN684877 \\
\hline & Chamusca & Santarém & 2009 & BxPt72CH & JN684848 & JN684878 \\
\hline & Ferreira do Zêzere & Santarém & 2009 & BxPt73FZ & JN684849 & JN684879 \\
\hline & Santa Comba Dão & Viseu & 2009 & BxPt74SCD & JN684850 & JN684880 \\
\hline \multirow{4}{*}{$\begin{array}{l}\text { Portugal } \\
\text { (Madeira Island) }\end{array}$} & São Gonçalo & Funchal & 2010 & OBxMad3F & JN684806 & JN684882 \\
\hline & São Vicente & São Vicente & 2010 & OBxMad4SV & JN684808 & JN684884 \\
\hline & Santa Cruz & Santa Cruz & 2010 & OBxMad18SC & JN684809 & JN684885 \\
\hline & Calheta & Calheta & 2010 & OBxMad22C & JN684810 & JN684881 \\
\hline \multirow[t]{3}{*}{ China } & Jiansu Province & - & - & BxChJs & JN684813 & JN684886 \\
\hline & Jiangxi Province & - & - & BxChJx & JN684814 & JN684887 \\
\hline & Shandong Province & - & - & BxChSD & JN684815 & JN684888 \\
\hline \multirow[t]{2}{*}{ Japan } & Unknown & - & - & BxJS10 & JN684816 & JN684889 \\
\hline & Unknown & - & - & BxJT4 & JN684817 & JN684890 \\
\hline \multirow[t]{2}{*}{ South Korea } & Unknown & - & - & BxKAs & JN684811 & JN684891 \\
\hline & Unknown & - & - & BxKBG & JN684812 & JN684892 \\
\hline \multirow[t]{2}{*}{ USA } & Unknown & - & - & BxUSA618 & JN684818 & JN684893 \\
\hline & Unknown & - & - & BxUSA745 & JN684819 & JN684894 \\
\hline
\end{tabular}


culture. Nematodes were centrifuged at $17982 \mathrm{~g}$ for $5 \mathrm{~min}$ and excess water removed. Genomic DNA was extracted with the JETQUICK Tissue DNA Spin Kit extraction kit (Genomed, Aventura, FL, USA), according to the manufacturer's protocol. DNA was used for the molecular analysis of ITS and IGS regions and ISSR marker. Nematode DNA was kept at $-20^{\circ} \mathrm{C}$ for further use.

\section{SEQUENCING OF THE ITS REGIONS}

Molecular identification of the 43 isolates was made using internal transcribed spacer (ITS) polymerase chain reaction (PCR) sequencing. Amplification of the ITS region (ITS1 and ITS2) was performed with a set of universal primers used for Bursaphelenchus species within the $x y$ lophilus group (Zhuo et al., 2011): ITS1A 5'-CGT AAC AAG GTA GCT GTA G-3' (Ferris et al., 1993) located in the $18 \mathrm{~S}$ region and ITS1B 5'-TTT CAC TCG CCG TTA CTA AGG-3', located in the 28S region (Vrain, 1993). The amplicon is approximately $950 \mathrm{bp}$ long. PCR reactions were conducted in $50 \mu \mathrm{l}$ PCR mixture containing $1.5 \mathrm{mM} \mathrm{MgCl}_{2}, 0.2 \mathrm{mM}$ of each dNTP, $1 \times$ PCR buffer (all Fermentas, Glen Burnie, MD, USA), $0.1 \mu \mathrm{M}$ of each primer (STABvida, Lisbon, Portugal), 0.05 units of Taq DNA Polymerase Recombinant (Fermentas) and $10 \mu \mathrm{l}$ template DNA. The PCR program consists of an initial denaturation step for $3 \mathrm{~min}$ at $94^{\circ} \mathrm{C}$, followed by 40 cycles of denaturation at $94^{\circ} \mathrm{C}$ for $1 \mathrm{~min}$, annealing at $48^{\circ} \mathrm{C}$ for $1 \mathrm{~min}$ and extension at $72^{\circ} \mathrm{C}$ for $1 \mathrm{~min}$. The last step was performed at $72^{\circ} \mathrm{C}$ during $2 \mathrm{~min}$. The PCR product was analysed by $1 \%$ agarose gel electrophoresis, stained in ethidium bromide. The amplified fragment was sequenced by STABvida, Portugal.

\section{SEQUENCING OF THE IGS REGIONS}

The IGS region from the 43 isolates was amplified, using a set of primers that amplifies the complete IGS fragment along with adjacent parts of the coding region (5S rRNA gene). The amplification product is approximately $500 \mathrm{bp}$. The primers were designed based on the conserved coding region of the 5S rRNA gene (Kang et al., 2004); forward primer for B. xylophilus 5'-TTA GTA CTT GGA TCG GAG ACG-3', forward primer for $B$. mucronatus 5'-TTA GTA CTT GGA ACG GAG ACG$3^{\prime}$ and reverse primer for both species 5'-CAT CGT TGC TTA ACT TGG CAG A-3'. PCR amplifications were conducted in $50 \mu \mathrm{l}$ PCR mixture containing $1 \times$ PCR buffer, $1.5 \mathrm{mM} \mathrm{MgCl}_{2}, 0.2 \mathrm{mM}$ of each dNTP (all Fermen- tas), $0.4 \mu \mathrm{M}$ of each primer (STABvida), 0.05 units of Taq DNA Polymerase Recombinant (Fermentas) and $5 \mu \mathrm{l}$ template DNA. The PCR reaction program started by one step at $96^{\circ} \mathrm{C}$ for $2.5 \mathrm{~min}$, followed by 35 cycles of $96^{\circ} \mathrm{C}$ for $1 \mathrm{~min}, 50^{\circ} \mathrm{C}$ for $2 \mathrm{~min}$ and $72^{\circ} \mathrm{C}$ for $3 \mathrm{~min}$; the last step was at $72^{\circ} \mathrm{C}$ for $6 \mathrm{~min}$. The PCR product was analysed by $1 \%$ agarose gel electrophoresis, stained in ethidium bromide. The amplified fragment was sequenced by STABvida, Portugal.

\section{ISSR FINGERPRINTS}

For the 43 isolates, genomic DNA was amplified using 14 different primers (Table 2), which are 12-20 bp long (Bornet \& Branchard, 2001). PCR amplification was conducted in a $25 \mu \mathrm{l}$ PCR mixture containing $1 \times$ PCR buffer, $4 \mathrm{mM} \mathrm{MgCl} 2,0.2 \mathrm{mM}$ of each dNTP (all Fermentas), $0.8 \mu \mathrm{M}$ of primer (STABvida), 0.1 units of Taq DNA Polymerase recombinant (Fermentas) and $5 \mu \mathrm{l}$ template DNA. The PCR programme consisted of one cycle at $96^{\circ} \mathrm{C}$ for $2.5 \mathrm{~min}$, followed by 35 cycles of $94^{\circ} \mathrm{C}$ for $20 \mathrm{~s}, 42-55^{\circ} \mathrm{C}$ for $45 \mathrm{~s}$ and $72^{\circ} \mathrm{C}$ for $2 \mathrm{~min}$; the last step of final extension was at $72^{\circ} \mathrm{C}$ for 6 min. Following PCR, the fingerprints for each primer were obtained in a $1 \%$ agarose gel stained with ethidium bromide.

\section{PhylOGENETIC ANALYSIS OF ITS AND IGS SEQUENCE}

ITS and IGS sequences were assembled and aligned using the ClustalW algorithm as implemented in BioEdit version 7.1.3.0 (Hall, 1999), under default alignment parameters. The sequences of ITS and IGS were submitted to GenBank under the accession numbers present in Table 1. Using MEGA5 version 5.05 (Tamura et al., 2011), phylogenetic relationships between isolates were reconstructed by the Neighbour-Joining (NJ) (Saitou \& Nei, 1987) and the Maximum Likelihood methods. Bootstrap analysis was performed with 1000 replicates (Felsenstein, 1985). Bursaphelenchus mucronatus (BmPt0) was used as outgroup.

\section{ANALYSIS OF ISSR FINGERPRINTS}

ISSR fingerprint patterns were converted into a binary data matrix by scoring the presence of a band as 1 and its absence as 0. Only the well distinguishable bands were used as markers for matrix construction. Each fingerprint was repeated at least twice to guarantee the reproducibility of the technique. The binary matrix was 
Table 2. List of primers used for Bursaphelenchus sp. isolates in ISSR analysis: primer sequences and annealing temperatures, total number of amplified bands, and percentage of polymorphic and phylogenetically-informative bands. Wobbles base pair code B: $C$, $G$ or T; D: A, Gor T; H: A, Cor T; R: A or G; V: A, Cor G; Y: Cor T.

\begin{tabular}{|c|c|c|c|c|c|}
\hline Primer & $\begin{array}{l}\text { Primer sequence } \\
\left(5^{\prime} \rightarrow 3^{\prime}\right)\end{array}$ & $\begin{array}{c}\text { Annealing } \\
\text { temperature }\left({ }^{\circ} \mathrm{C}\right)\end{array}$ & $\begin{array}{l}\text { Total number of } \\
\text { amplified bands }\end{array}$ & $\begin{array}{l}\text { Polymorphic } \\
\text { bands }(\%)\end{array}$ & $\begin{array}{c}\text { Phylogenetically } \\
\text { informative bands (\%) }\end{array}$ \\
\hline 11 & $(\mathrm{GA})_{9}-\mathrm{CCA}$ & 50 & 15 & 100 & 73 \\
\hline 25 & $(\mathrm{AC})_{9}-\mathrm{TG}$ & 55 & - & - & - \\
\hline 26 & $(\mathrm{AC})_{9}-\mathrm{GA}$ & 55 & 16 & 94 & 94 \\
\hline 54 & $(\mathrm{TC})_{9}-\mathrm{CG}$ & 50 & 12 & 100 & 83 \\
\hline 188 & CGT-(CA) 8 & 55 & 14 & 100 & 40 \\
\hline 190 & CAG- $(\mathrm{GT})_{9}$ & 55 & 7 & 100 & 71 \\
\hline 841 & $(\mathrm{GA})_{8}-\mathrm{YC}$ & 50 & 11 & 64 & 36 \\
\hline 848 & $(\mathrm{CA})_{8}-\mathrm{RG}$ & 42 & 13 & 100 & 92 \\
\hline 857 & $(\mathrm{AC})_{8}-\mathrm{YG}$ & 50 & 10 & 100 & 100 \\
\hline 888 & $\mathrm{BDB}-(\mathrm{CA})_{7}$ & 55 & 7 & 100 & 100 \\
\hline 890 & VHV-(GT) $)_{7}$ & 55 & 10 & 100 & 100 \\
\hline 1423 & HVH-(TGT) $)_{5}$ & 50 & 21 & 100 & 57 \\
\hline 1424 & $\mathrm{BDB}-(\mathrm{CAC})_{5}$ & 50 & 6 & 100 & 100 \\
\hline 1425 & $\mathrm{BDV}-(\mathrm{CAG})_{5}$ & 50 & 12 & 100 & 75 \\
\hline
\end{tabular}

analysed with NTSYS-PC version 2.21 (Rohlf, 2008), using the Dice or Nei and $\mathrm{Li}$ (1979) coefficient to generate a genetic distance similarity matrix. Cluster analysis of this matrix was made with unweighted pair group method using arithmetic averages (UPGMA) in the module SAHN (sequential, agglomerative, hierarchical and nested) clustering method. The resulting dendrogram was compared with the original similarity matrix and the cophenetic correlation coefficient $(r)$ and Mantel's test $(t)$ value (Mantel, 1967) were calculated to evaluate the goodness-of-fit of data.

\section{Results}

\section{SEQUENCING OF THE ITS REGIONS}

For the 43 isolates, a PCR product of approximately $950 \mathrm{bp}$ containing the entire 5.8S rRNA gene and both ITS1 and ITS 2 regions was obtained and sequenced (accession numbers in Table 1). One isolate of B. mucronatus (BmPt0) was used as outgroup (accession number of B. mucronatus ITS sequence is JN684820). The phylogenetic analysis of this region showed $100 \%$ sequence identity among geographical isolates from Portugal as well as with isolates from Japan, China, South Korea and isolate BxUSA618 (data not shown), with the exception of isolate BxMad3F, which shares $99.8 \%$ sequence similarity with all other sequences, and $98.8 \%$ of similarity with iso- late BxUSA745. Isolate BxUSA745 has a separate position from all other isolates, sharing a similarity of $99 \%$ sequence with all the isolates, except BxMad3F (98.8\% sequence similarity). Bursaphelenchus mucronatus isolate $(\mathrm{BmPt} 0)$, shares a similarity of $88.4 \%$ with all isolates, with the exceptions of BxMad3F (sequence similarity $88.3 \%$ ) and BxUSA745 (87.9\% sequence similarity).

\section{SEQUENCING OF THE IGS REGIONS}

Forty-three isolates of $B$. xylophilus were analysed using IGS sequences. Bursaphelenchus mucronatus (BmPt0) was used as outgroup. IGS PCR products were about 500 bp long and were sequenced and submitted to GenBank under the accession numbers presented in Table 1 (accession number of $B$. mucronatus IGS sequence is JN684895). No polymorphisms were found among Portuguese isolates, showing that this marker is not informative enough to be used in the study of genetic variability between Portuguese isolates from different geographic locations, i.e., IGS sequences from Portuguese isolates do not show any intraspecific variability. Similar phylogenetic trees were obtained with both Neighbour-Joining and Maximum Likelihood methods (data not shown). One major cluster was obtained which contained all Portuguese along with the two Korean isolates (Fig. 2). These isolates are all $100 \%$ identical. Isolates from China and Japan form a separate cluster with $100 \%$ sequence identity, which groups with the first one. The two USA iso- 


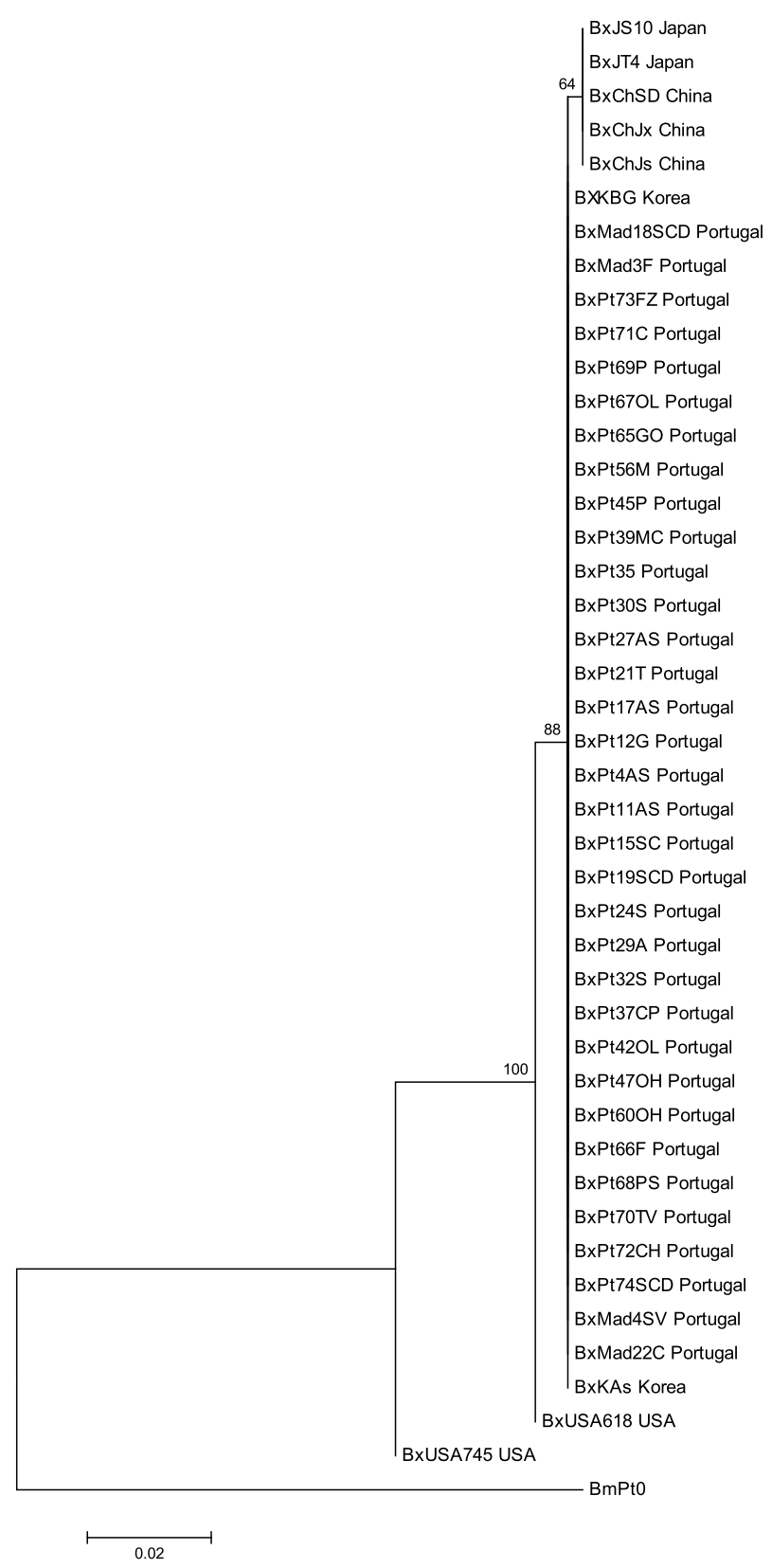

Fig. 2. Neighbour-joining phylogenetic tree based on rRNA IGS sequences of Bursaphelenchus xylophilus isolates (alignment length $450 \mathrm{bp}$ ). Percentage bootstrap is indicated on internal branches (1000 replicates); scale bar indicates 0.02 substitutions per site. Tamura 3-parameter nucleotide substitution model (Tamura \& Kumar, 2002) was used.

lates have separate positions being more distantly related to all other isolates. Isolate BxUSA618 shares approximately $99 \%$, whereas BxUSA745 only shares $97-98 \%$ sequence similarity with all other isolates. Furthermore, the sequence identity between isolates BxUSA618 and BxUSA745 is $98 \%$, which may suggest that North American populations have a high genetic diversity.

\section{ISSR FINGERPRINTS}

Forty-three isolates of B. xylophilus were analysed using ISSR technique. Bursaphelenchus mucronatus isolate $(\mathrm{BmPt} 0)$ was used as outgroup. All fingerprints were repeated at least three times. From the 14 primers used, 13 produced clear and reproducible banding patterns. Amplification of genomic DNA from the 44 Bursaphelenchus isolates with the 13 primers yielded a total of 154 ISSR markers, of which 149 are polymorphic and 117 are phylogenetically informative (Table 2). The number of bands per isolate varies between 1 and 10. Each primer generated a set of bands ranging from 500 to $2000 \mathrm{bp}$ (Fig. 3). A binary matrix was assembled for the 13 primers set and cluster analysis compared Portuguese with foreign isolates. The relationships between the B. xylophilus isolates used in this study have a good bootstrap support (all values above 52\%; Fig. 4). This dendrogram is supported by a significantly high cophenetic correlation coefficient of 0.97 and a Mantel's test $(t)$ of 7.26. The obtained dendrogram clearly illustrates the outgroup position of $B$. тисronatus. The dendrogram shows a large cluster with $56 \%$ bootstrap support, which includes all foreign and Portuguese isolates, with the exception of isolate BxPt73FZ, and the Madeira isolates BxMad4SV and BxMad3F.

The three isolates from China group together with similarities levels between 81 and $91 \%$. Japanese and Korean isolates are distributed across different branches of the dendrogram. Korean isolates are more similar to Japanese isolates than to Chinese isolates, considering that isolates BxJT4 and BxKAs group together with a similarity level of $91 \%$. The two North American isolates do not form a cluster and show $63 \%$ similarity between them.

From the 34 Portuguese isolates, 17 (BxPt4AS, BxPt11AS, BxPt12G, BxPt15SC, BxPt17AS, BxPt19SCD, BxPt21T, BxPt24S, BxPt29S, BxPt30S, BxPt32S, BxPt35PM, BxPt37CP, BxPt39MC, BxPt42OL, $\mathrm{BxPt} 45 \mathrm{P}$ and $\mathrm{BxPt} 47 \mathrm{OH}$ ) have identical fingerprints with all 13 primers. These 17 isolates that group together were collected prior to 2008, being distributed in the Setúbal, Leiria and Castelo Branco districts and representing the initial spread of the disease in continental Portugal, from 1999-2008. Seventeen isolates were collected from 20092010 and represent the new outbreaks of the disease 


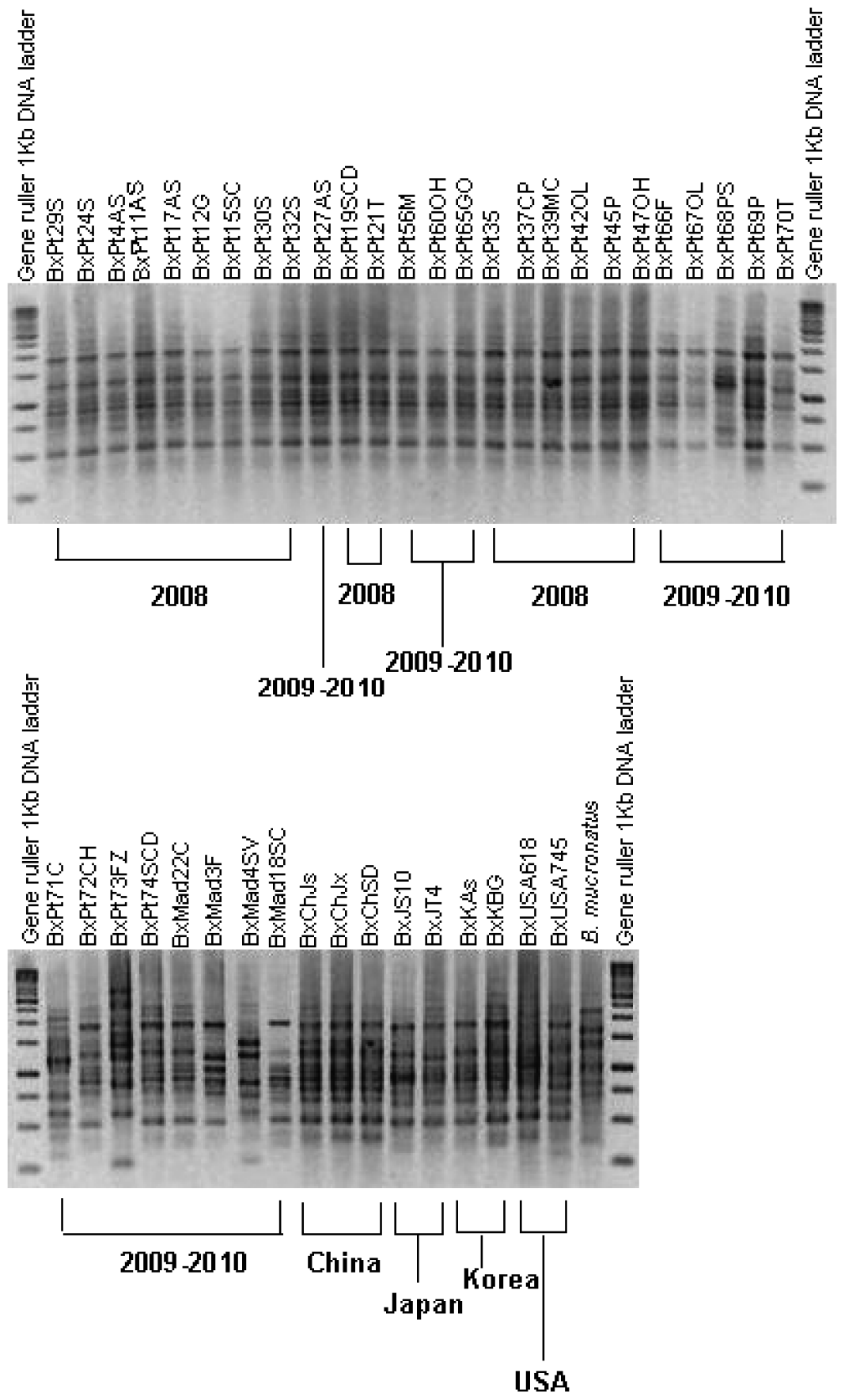

Fig. 3. ISSR profiles from 43 Bursaphelenchus xylophilus isolates with primer 1423.

in continental Portugal and Madeira: BxPt27As (Setúbal district), BxPt56M/BxPt60OH/BxPt65GO/BxPt68PS/ BxPt69P (Coimbra district), BxPt66F/BxPt67OL (Castelo Branco district), BxPt70TV (Lisboa district), BxPt71C/
BxPt72CH/BxPt73FZ (Santarém district), BxPt74SCD (Viseu district), BxMad3F (Funchal district), BxMad4SV/ BxMad9SV (São Vicente district), BxMad18SC (Santa Cruz district) and BxMad22C (Calheta district). Twelve 


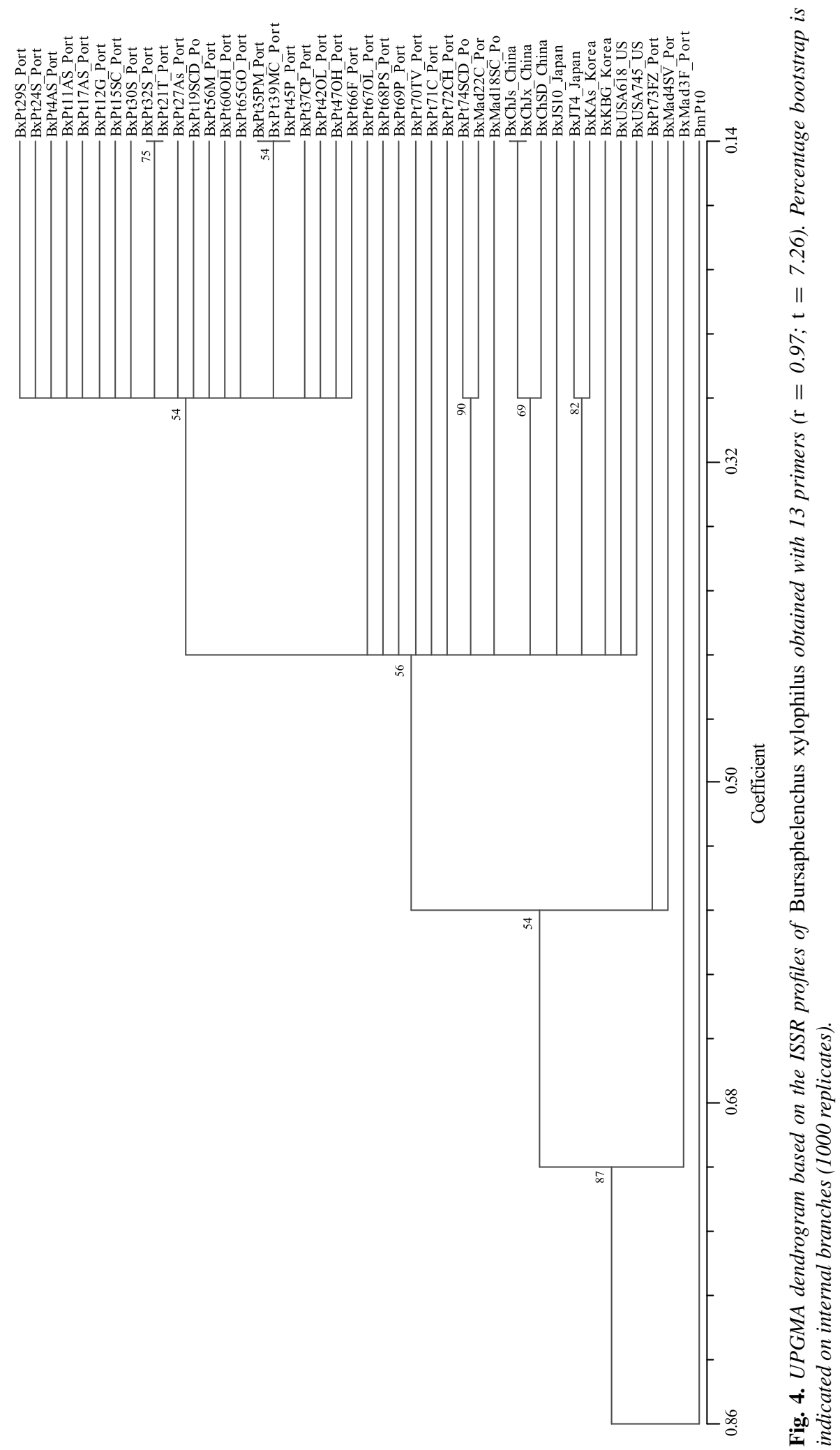


of these isolates show different fingerprints with all primers from those detected up to 2008, which have different levels of variability, revealing the existence of intraspecific variability among Portuguese isolates. Isolates BxPt27AS, BxPt56M, BxPt60OH, BxPt65GO and BxPt66F show different banding patterns only for some of the primers and thus still group with isolates up to 2008 in the dendrogram (Fig. 4). Examining the distribution of these isolates in the dendrogram, Portuguese isolates collected from 1999-2008 all group in the same clade with similarity levels between 84 and $99 \%$. However, Portuguese isolates collected in 2009-2010 are distributed across different branches of the dendrogram.

Madeira isolates BxMad18SC (Santa Cruz district) and BxMad22C (Calheta district), share many bands with Portuguese isolates collected up to 2008 and Asian isolates (Fig. 3). Isolate $\mathrm{BxMad} 22 \mathrm{C}$ groups together with isolate $\mathrm{BxPt74SCD}$, with a similarity level of $82 \%$. Isolates BxMad3F and BxMad4SV share bands with both Asian and USA isolates, exhibiting high levels of polymorphism (Fig. 3). Furthermore, isolate BxMad3F has a clearly separate position on the dendrogram since it shows approximately the same low similarities (35-54\%) with all isolates.

\section{Discussion}

The pine wood nematode is native to North America (Kanzaki \& Futai, 2002) and widely distributed throughout Canada, USA and Mexico (CABI/EPPO, 1999). In these areas, the nematode co-evolved with the different North American pine species during millions of years, therefore causing no disease. Most probably, North America is the region where B. xylophilus populations have the highest genetic diversity (Vieira et al., 2007).

In Portugal, PWN was successfully restricted to the Setúbal Peninsula for several years immediately following the first report (Mota et al., 1999). This was mainly due to strong and specific measures for control of inland circulation of wood and wood products from the original affected area. However, in 2008, the nematode was found in new outbreak spots in central and northern regions of the country (Rodrigues, 2008) and, more recently, in one of the islands of the Madeira archipelago (Fonseca et al., 2010).

The first study using a significant number of $B$. xylophilus from Portugal was performed by Vieira et al. (2007), using 24 isolates from the initial affected area, the Setúbal Peninsula, the only region where the disease was detected until 2008. In this study, the authors showed that there was almost no genetic diversity among isolates and that the Portuguese isolates grouped with Chinese isolates.

To understand the origin and genetic diversity of the PWN found in the new areas in continental Portugal and Madeira, 34 isolates representing the different geographic areas were studied using IGS sequences and ISSR fingerprints. This is the first study where a significant number of B. xylophilus isolates from the initial affected area in the Setúbal Peninsula, as well as from the new outbreaks of the disease in continental Portugal and Madeira, have been analysed. ITS sequences confirmed all 34 Portuguese isolates as B. xylophilus. No intraspecific variability among isolates was found. Only isolate BxUSA745 from USA groups in a separate position from all the other isolates. Using IGS sequencing, no significant intraspecific variability was detected among isolates of $B . x y l o-$ philus. Both USA isolates are distantly related to all other isolates, isolate BxUSA745 having a clear separate position on the phylogenetic tree. Chinese and Japanese isolates group together. All Portuguese isolates group with Korean isolates. Moreover, no clustering of the isolates according to their geographic origin was obtained.

In the dendrogram obtained from the ISSR fingerprint analysis, all Portuguese isolates collected prior to 2008 group together with similarities of $84-99 \%$, indicating a lack of genetic diversity and suggesting a single introduction, which is in agreement with the results of Vieira $e t$ al. (2007). Observing the distribution of isolates collected in 2009-2010 in continental Portugal, there are five isolates (BxPt27As, BxPt56M, BxPt60OH, BxPt65GO and BxPt66F) grouping with the isolates collected up to 2008 with similarities above $86 \%$. This suggests a spread of the disease from the initial affected area to new outbreaks, which may have occurred with great probability considering the heavy traffic of vehicles carrying wood products from the Lisbon-Setúbal area to the centre and north of Portugal, where a number of industries process pine wood for furniture. The insect vector Monochamus galloprovincialis is known to occur well inside the centre of the country, quite far ( $c a$ 200-300 km) north of the Setúbal Peninsula, for example, in the region of Penacova, near Coimbra. Furthermore, it is known to occur throughout the continental territory (Sousa et al., 2001, 2002; Penas et al., 2006). On the other hand, continental isolate BxPt73FZ has a separate position from all other isolates, suggesting a new introduction in continental Portugal, possibly from the native North American population. 
The results obtained from the Madeira isolates suggest a high genetic diversity of $B$. xylophilus population on the island. Isolates BxMad4SV and BxMad3F are distinct from all other isolates and show low similarity values, which suggests new introductions in the island. The same insect vector, $M$. galloprovincialis, is known to occur on the island for more than 15 years, at least since 1996, but possibly much longer (Erber \& Aguiar, 1996). This could explain the easy spread of the nematode, unnoticed for several years until its recent detection (Fonseca et al., 2010). The other isolate from Madeira, BxMad22C, groups with isolate BxPt74SCD with a similarity of $82 \%$, suggesting that at least part of the Madeira population is related to the mainland population.

Previous studies on B. xylophilus populations have shown intraspecific variability between isolates from different geographic origins using ISSR (Metge \& Burgermeister, 2006), revealing a significant degree of genetic divergence according to geographic distribution. Two major clusters were identified: one including the North American isolates (Canada and USA) displaying a high level of genetic diversity, and a second cluster including Asian and Portuguese isolates at a lower genetic diversity level. Another study, using AFLP, suggested that China was affected directly from North America or from neighbouring countries such as Japan (Cheng et al., 2008). Other studies with Korean isolates using microsatellites and AFLP (Jung et al., 2010a, b), suggest that the high genetic diversity found among some Korean populations is due to the gene flow between China, Japan and Korea. The present results support previous reports (Metge \& Burgermeister, 2006; Vieira et al., 2007), namely IGS- and ISSRbased grouping of most Portuguese isolates with Asian isolates.

Until now, little information about B. xylophilus markers has been available, but the recent release of the entire genome sequence of B. xylophilus (Kikuchi et al., 2011) will be a challenge and opportunity to discover novel suitable markers to study intraspecific variability, determine pathways of disease spread and follow the evolution of introduced isolates. The increase in global trade has an important impact on natural ecosystems, making the invasion of B. xylophilus a serious ecological and economic problem. Bursaphelenchus xylophilus, in particular, damages conifers (Pinus spp.) making PWD one of the most serious problems of forests worldwide. The understanding of the disease and its spread will be of paramount importance to draw up new measures to avoid the dissemination of PWN to other countries. Future research on B. xylophi- lus must continue to follow the evolution and spread of this biological invader in pine forests.

\section{Acknowledgements}

This research was supported by the EC 7th Framework project REPHRAME (KBBE.2010.1.4-09, 'Analysis of the potential of the pine wood nematode (Bursaphelenchus xylophilus) to spread, survive and cause pine wilt in European coniferous forests in support of EU plant health policy'), and by a national project from the Portuguese National Forestry Authority (AFN, Autoridade Florestal Nacional), 'O nemátode da madeira do pinheiro (NMP), Bursaphelenchus xylophilus'. We would like to thank Dr Bo-Guang Zhao, Nanjing Forestry University, China, Dr Hyerim Han, Korea Forest Research Institute, South Korea, Dr K. Futai, Kyoto University, Japan, Dr Robin Giblin-Davis, University of Florida, USA and Dr Isabel Abrantes, Coimbra University, Portugal, for providing nematode cultures of B. xylophilus. This paper is a portion of the $\mathrm{PhD}$ dissertation of the first author, who was supported by a doctoral scholarship from FCT (Fundação para a Ciência e Tecnologia) (SFRH/BD/22086/2005).

\section{References}

Аввот, P. (2001). Individual and population variation in invertebrates revealed by inter-simple sequence repeats (ISSRs). Journal of Insect Science 1, 8. Available online at http://www.insectscience.org/1.8.

Abelleira, A., PicoAgA, A., Mansilla, J.P. \& Aguin, O. (2011). Detection of Bursaphelenchus xylophilus, causal agent of pine wilt disease on Pinus pinaster in North-western Spain. EPPO Bulletin 39, 344-353.

Bergdahl, D.R. \& HALIK, S. (1999). Inoculated Pinus sylvestris serve as long-term hosts for Bursaphelenchus xylophilus. In: Futai, K., Togashi, K. \& Ikeda, T. (Eds). Sustainability of pine forest in relation to pine wilt and decline: proceedings of international symposium. Tokyo, Japan, Shokada, pp. 73-78.

BLOUIN, M. (2002). Molecular prospecting for cryptic species of nematodes: mitochondrial DNA versus internal transcribed spacer. International Journal for Parasitology 32, 527-531.

BORnET, B. \& BRANCHARD, M. (2001). Nonanchored Inter Simple Sequence Repeat (ISSR) markers: reproducible and specific tools for genome fingerprinting. Plant Molecular Biology Reporter 19, 209-215.

Braasch, H., Tomiczek, C., Metge, K., Hoyer, U., Burgermeister, W., Wulfert, I. \& Schonfeld, U. (2001). Records of Bursaphelenchus spp. (Nematoda, Parasi- 
taphelenchidae) in coniferous timber imported from the Asian part of Russia. Forest Pathology 31, 129-140.

CABI/EPPO (1999). Distribution maps of plant diseases. Wallingford, UK, CABI Publishing. Available online at http:// www.CABI.org/DMPD

Cheng, H., Lin, M., LI, W. \& FAng, Z. (1983). The occurrence of a pine wilting disease caused by a nematode found in Nanjing. Forest Pest and Disease 4, 1-5.

Cheng, X.Y., Cheng, F.X., XU, R.M. \& Xie, B.Y. (2008). Genetic variation in the invasive process of Bursaphelenchus xylophilus (Aphelenchida: Aphelenchoididae) and its possible spread routes in China. Heredity 100, 356-365.

Erber, D. \& Aguiar, A.M.F. (1996). New and remarkable species of the Coleopterous fauna of Madeira. Boletim do Museu Municipal do Funchal 48, 41-62.

Evans, H.F., MCNAmara, D.G., BRAasch, H., Chadouef, J. \& Magnusson, C. (1996). Pest risk analysis (PRA) for the territories of the European Union (as PRA area) on Bursaphelenchus xylophilus and its vectors in the genus Monochamus. EPPO Bulletin 26, 199-249.

FELSENSTEIN, J. (1985). Confidence limits on phylogenies: an approach using the bootstrap. Evolution 39, 783-791.

FERRIS, V.R., FERRIS, J.M. \& FAGHIHI, J. (1993). Variation in spacer ribosomal DNA in some cyst forming species of plant parasitic nematodes. Fundamental and Applied Nematology 16, 177-184.

Fonseca, L., Lopes, A., Cardoso, J., Pestana, M., Abreu, F., Nunes, N., Mota, M. \& Abrantes, I. (2010). The pinewood nematode, Bursaphelenchus xylophilus, in Madeira Island. 30th International Symposium of European Society of Nematologists, Vienna, Austria, p. 176. [Abstr.]

FUCHS, A.G. (1937). Neue parasitische und halbparasitische Nematoden bei Borkenkafern und einige andere Nematoden. I. Teil. Zoologische Jahrbuecher Abteilung fuer Systematik Oekologie und Geographie der Tiere 70, 291-380.

Gu, J., BraAsch, H., Burgermeister, W., BrandstetTER, M. \& ZHANG, J. (2006). Description of Bursaphelenchus yongensis sp. n. (Nematoda: Parasitaphelenchidae) isolated from Pinus massoniana in China. Russian Journal of Nematology 14, 91-99.

HALL, T.A. (1999). BioEdit: a user-friendly biological sequences alignment editor and analysis program for Windows 95/98/NT. Nucleic Acids Symposium 41, 95-98.

Jones, C.J., Edwards, K.J., CASTAGLione, S., Winfield, M.O., Sala, F., Wiel, C., Bredemeijer, G., Vosman, B., Matthes, M., DALY, A., ET AL. (1997). Reproducibility testing of RAPD, AFLP and SSR markers in plants by a network of European laboratories. Molecular Breeding 3, 381-390.

JUNG, J., HAN, H., RYU, S.H. \& KIM, W. (2010a). Microsatellite variation in the pinewood nematode, Bursaphelenchus $x y$ lophilus (Steiner and Bührer) Nickle in South Korea. Genes \& Genomics 32, 147-154.
JUNG, J., HAN, H., RYU, S.H. \& KIM, W. (2010b). AFLP (amplified fragment length polymorphism) analysis and genetic variation of pinewood nematode, Bursaphelenchus xylophilus in South Korea. Animal Cells and Systems 14, 31-36.

KANG, J.S., ChOI, K.S., Skin, S.C., Moon, I.S., LeE, S.G. \& LEE, S.H. (2004). Development of an efficient PCR-based diagnosis protocol for the identification of the pinewood nematode, Bursaphelenchus xylophilus (Nematoda: Aphelenchoididae). Nematology 6, 279-285.

KANZAKI, N. \& FUTAI, K. (2002). A PCR primer set for determination of phylogenetic relationships of Bursaphelenchus species within the xylophilus group. Nematology 4, 35-41.

Kikuchi, T., Cotton, J.A., Dalzell, J.J., Hasegawa, K., Kanzaki, N., McVeigh, P., Takanashi, T., Tsai, I.J., Assefa, S.A., CoCK, P.G.A., ET AL. (2011). Genomic insights into the origin of parasitism in the emerging plant pathogen Bursaphelenchus xylophilus. PLoS Pathogens 7(9), e1002219. DOI:10.1371/journal.ppat.1002219

KIM, H.J., CHOI, Y.K. \& MIN, B.R. (2001). Variation of the intergenic spacer (IGS) region of ribosomal DNA among Fusarium oxysporum formae speciales. Journal of Microbiology 9, 265-272.

KIYOHARA, T. \& Bolla, R.I. (1990). Pathogenic variability among populations of the pinewood nematode, Bursaphelenchus xylophilus. Forest Science 36, 1061-1076.

MamiYA, Y. (2004). Pine wilt disease in Japan. In: Mota, M. \& Vieira, P. (Eds). The pinewood nematode, Bursaphelenchus xylophilus. Proceedings of an International Workshop, University of Evora, Portugal, 20-22 August, 2001. Nematology Monographs and Perspectives 1. Leiden, The Netherlands, Brill, pp. 9-20.

MANTEL, N. (1967). The detection of disease clustering and a generalized regression approach. Cancer Research 27, 209220.

Metge, K. \& Burgermeister, W. (2006). Intraspecific variation in provenances of Bursaphelenchus xylophilus (Nematoda: Aphelenchoididae) revealed by ISSR and RAPD fingerprints. Journal of Plant Diseases and Protection 113, 275282.

Metge, K., BraAsch, H., Gu, J. \& Burgermeister, W. (2006). Interspecific variation in ITS rDNA of Bursaphelenchus species (Nematoda: Parasitaphelenchidae) of different groups. Russian Journal of Nematology 14, 147-158.

Mota, M., BraAsch, H., Bravo, M.A., Penas, A.C., Burgermeister, W., Metge, K. \& SousA, E. (1999). First report of Bursaphelenchus xylophilus in Portugal and in Europe. Nematology 1, 727-734.

NEI, M. \& LI, W.H. (1979). Mathematical model for studying genetic variation in terms of restriction endonucleases. Proceedings of the National Academy of Sciences of the United States of America 76, 5269-5273.

Penas, A.C., Bravo, M.A., Naves, P., Bonifácio, L., SousA, E. \& MotA, M. (2006). Species of Bursaphelenchus Fuchs, 1937 (Nematoda: Parasitaphelenchidae) and other 
nematode genera associated with insects from Pinus pinaster in Portugal. Annals of Applied Biology 148, 121-131.

REDDY, M.P., SARLA, N. \& SidDiQ, E.A. (2002). Inter simple sequence repeat (ISSR) polymorphism and its application in plant breeding. Euphytica 128, 9-17.

Robertson, L., Arcos, C.S., Escuer, M., Merino, S.R., Esparrago, G., Abelleira, A. \& Navas, A. (2011). Incidence of the pinewood nematode Bursaphelenchus $x y$ lophlius Steiner \& Buhrer, 1934 (Nickle, 1970) in Spain. Nematology 13, 755-757.

RoDRIGUES, J. (2008). Eradication program for the pinewood nematode in Portugal. In: Mota, M. \& Vieira, P. (Eds). Pine wilt disease: a worldwide threat to forest ecosystems. Heidelberg, Germany, Springer, pp. 5-14.

RoHLF, F.J. (2008). NTSYSpc: numerical taxonomy system, ver. 2.20. Setauket, NY, USA, Exeter Publishing.

SAITOU, N. \& NeI, M. (1987). The neighbor-joining method: a new method for reconstructing phylogenetic trees. Molecular Biology and Evolution 4, 406-425.

ShimaZU, M. (2006). Current status on research and management of pine wilt disease in Japan. In: Han, H.R., Koh, S.H., Jung, C.S., Chung, Y.J. \& Shin, S.C. (Eds). Current status on research and management of pine wilt disease. Seoul, Korea, Korea Forest Research Institute, pp. 1-18.

Shin, S. \& HAN, H. (2006). Current status on research and management of pine wilt disease in Korea. In: Han, H.R., Koh, S.H., Jung, C.S., Chung, Y.J. \& Shin, S.C. (Eds). Current status on research and management of pine wilt disease. Seoul, Korea, Korea Forest Research Institute, pp. 31-44.

Sousa, E., Bravo, M.A., Pires, J., Naves, P., Penas, A.C., Bonifácio, L. \& MotA, M. (2001). Bursaphelenchus xylophilus (Nematoda; Aphelenchoididae) associated with Monochamus galloprovincialis (Coleoptera; Cerambycidae) in Portugal. Nematology 3, 89-91.

SOUTHEY, J.F. (1986). Laboratory methods for work with plant and soil nematodes. London, UK, Ministry of Agriculture Fisheries and Food, HMSO, 202 pp.

Steiner, G. \& Buhrer, E.M. (1934). Aphelenchoides xylophilus n. sp., a nematode associated with blue-stain and other fungi in timber. Journal of Agricultural Research 48, 949951.

Sutherland, J.R. \& Peterson, M. (1999). The pinewood nematode in Canada: history, distribution, hosts, potential vectors and research. In: Futai, K., Togashi, K. \& Ikeda, T. (Eds). Sustainability of pine forests in relation to pine wilt and decline: proceedings of an international symposium. Tokyo, Japan, Shokado Shoten, pp. 247-253.

SUZUKI, K. (2002). Pine wilt disease - a threat to pine forest in Europe. Dendrobiology 48, 71-74.

TAmurA, K. \& Kumar, S. (2002). Evolutionary distance estimation under heterogeneous substitution pattern among lineages. Molecular Biology and Evolution 19, 1727-1736.
Tamura, K., Peterson, D., Peterson, N., Stecher, G., NEI, M. \& KUMAR, S. (2011). MEGA5: molecular evolutionary genetics analysis using maximum likelihood, evolutionary distance, and maximum parsimony methods. Molecular Biology and Evolution 28, 2731-2739.

TKACZ, B.M. (2002). Pest risks associated with importing wood to the United States. Canadian Journal of Plant Pathology 24, 111-116.

TomiczeK, C., BraAsch, H., Burgermeister, W., Metge, K., Hoyer, U. \& Brandstetter, M. (2003). Identification of Bursaphelenchus spp. isolated from Chinese packaging wood imported to Austria. Nematology 5, 573581.

Tomminen, J., Halik, S. \& Berglahl, D.R. (1991). Incubation temperature and time effects on life stages of Bursaphelenchus xylophilus in wood chips. Journal of Nematology 24, 477-484.

Vieira, P., Burgermeister, W., Mota, M., Metge, K. \& SILVA, G. (2007). Lack of genetic variation of Bursaphelenchus xylophilus in Portugal revealed by RAPD-PCR analyses. Journal of Nematology 39, 118-126.

VRAIN, T.C. (1993). Restriction fragment length polymorphism separates species of the Xiphinema americanum group. Journal of Nematology 25, 361-364.

WEBSTER, J. (2004). The pine wood nematode: implications of factors past and present for pine wilt disease. In: Mota, M. \& Vieira, P. (Eds). The pinewood nematode, Bursaphelenchus xylophilus. Proceedings of an International Workshop, University of Evora, Portugal, 20-22 August, 2001. Nematology Monographs and Perspectives 1. Leiden, The Netherlands, Brill, pp. 55-64.

Webster, J. \& Mota, M. (2008). Pine wilt disease: global issues, trade and economic impact. In: Mota, M. \& Vieira, P. (Eds). Pine wilt disease: a worldwide threat to forest ecosystems. Heidelberg, Germany, Springer, pp. 1-3.

YANO, M. (1913). Investigations on the cause of pine mortality in Nagasaki prefecture. Sanrin-Koho 4, 1-14.

Yi, C., BYUn, B., PARK, J., YANG, S. \& CHANG, K. (1989). First finding of the pine wood nematode, Bursaphelenchus xylophilus (Steiner \& Buhrer) Nickle and its insect vector in Korea. Research Reports of the Forestry Research Institute Seoul 38, 141-149.

Zhuo, K., Luo, M., CUI, R.Q. \& LiaO, J.L. (2011). A multiplex one-step PCR method for the simultaneous identification of Bursaphelenchus xylophilus, B. mucronatus and B. douithree species within the xylophilus group. Forest Pathology 41, 66-69.

Zietkiewicz, E., Rafalski, A. \& Labuda, D. (1994). Genome fingerprinting by simple sequence repeat (SSR)anchored polymerase chain reaction amplification. Genomics 20, 176-183. 